\title{
E-Healthy at the Front Edge in Medicine Science
}

\author{
Yan Wang ${ }^{1,2 *}$ \\ ${ }^{1}$ The American Physiology Society Member, USA \\ ${ }^{2}$ The Jenny Medical Foundation Corporation Chairman, USA
}

ISSN: 2689-2707

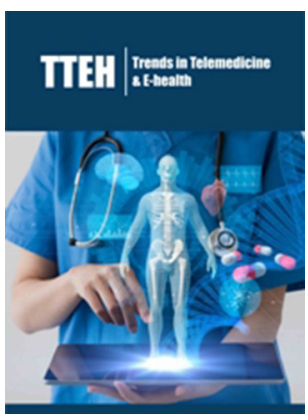

*Corresponding author: Yan Wang, The American Physiology Society Member, The Jenny Medical Foundation Corporation Chairman, USA

\section{Submission: 非 April 08, 2019}

Published: 埔April 10, 2019

Volume 1 - Issue 3

How to cite this article: Yan W Mucosal E-Healthy at the Front Edge in Medicine Science. Surg Med Open Acc J 1(3). TTEH. 000515. 2019. DOI: 10.31031/TTEH.2019.01.000515

Copyright@ Yan Wang, This article is distributed under the terms of the Creative Commons Attribution 4.0 International License, which permits unrestricted use and redistribution provided that the original author and source are credited.

\section{Editorial}

Current times, E-Healthy is the modern words to define the branch through high technique to use in medicine science, the media tools can include computer. digital devices (camera, recorder), telephone, mobile, and information platform, the Media usual belong to the field of information engineer and information development; E-healthy is the representative of computer science, information revolution, data digitalization, it reflects Medicine in human application. Now E-Healthy in medicine has the priority to assist that transfer data, make diagnosis and give treatment; rely on the E-Healthy, remote meeting or conference can hold in one media for persons spread in various ares in the world to attend that, since it can access rapid to transfer information and guidance to more broad area. However, is E-Healthy more trust area in medicine, how far it can go and assistant us in Medicine Science, it is at front edge to adventure in medicine science $[1,2]$.

The mediate for E-Healthy using to build up is network, it can be local area or wide area net, as some influential company in the world as Apple, Amazon or Orbitz using network to setup systematic information and procedure. Now medicine science has used the network to manage university, medicine school, library or hospital as design gene sequence, statistic processing to human resource management The requirement for E-Healthy has made medicine science at the front edge to develop the relationship of classical science with information revolution, development brings us more novel and engineerable, it is at critical role to us then.

As I analyzing, the more support E-Healthy system may consider of devices products as Apple Inc, Lenovo or Dell company by which influential, riched products and market occupied. For Apple Inc, it has found on April 1, 1976, it is an American multinational technology company, the company designs, develops, and sells consumer electronics, computer software, and online services. It's hardware products include the iPhone, iPad, tablet computer, Mac personal computer as well as iPod portable media player, Apple TV digital media player, and the Home Pod smart speaker, and the Apple's software includes the macOS, IOS operating systems, Safari web browser as well as more iLife and iWork creativity products, some of them are refinement and elegent.

In near end of the twenty centuries before 2000, E-Time was coming and almost strange to all of us, there were no one in fantasy to understand one person one computer or other device to work and contact. The day in 1993, I began my graduation study at Fudan University Medicine College in China, I have taken the courses on DBASE and DOS for computer language study, when I entered the machine room, there arranged one student used one desk computer at one desk; the desk computer looked common as many years later when I bought my first desk computer in 2000. The computer language is 0 or 1 in unlimited varied repeat sequence, I took the required basic courses, and obtained score 92 in 100 scale with 108 credit hours. For my career is in Medicine at Pediatrics and Emergency Medicine [3], then the college opened the course on computer in prospectively, I was curiosity in the beginning. Current E-Healthy has invaded many areas in Medicine, in hospital: doctors writing prescription on computer; in organization society: committees meet in telemedicine; in library: information 
digitalization. Currently I have built up my owner corporation the Jenny Medical Foundation Corporation and register it at the State of Florida Department of States, being the Chairman as well as the title of attending doctor, professor, director and academic committee, I have made the mission that bases in the education and development of medicine, provide knowledge and chance to different persons or groups in the world, and pursue the communication related with survive, charity and evolution. I thought the high technique development has in one important reason for me to manage in possible to make medicine more access to extensive area to harvest contribution.

The development for using E-healthy in Medicine has been the decades years, then the influence is remarkable in application at college, hospital and medical company, however, do the E-healthy can be liable or relied on over traditional communication or how much can E-healthy replace and assistant us in medicine? As the case, we can imagine the communication by the new E-Healthy concept for presentation in medicine conferences, in the traditional, the professional group persons meet together in the same hall in discussion of development and advancement for medicine, they may come from near neighbor or far from anther nations; then in the E-healthy time, therefore, we can apply devices to work on E- presentation, also it can take over crossing time and distance for attendees to discussion, it is the E-healthy bring us extension to involve in medicine science. One day in the future, the critical professional group hold a confidential meeting, the academic decorated office with higher back chair around a wood desk, the laptop device put ahead the chair on the desk; it is the time to start the meeting; the virtual meeting room as the power on for all devices, immediately the attendees' body shape sit on the chair visible in digital bright line, as the true persons may still in far distance away of the meeting, however, the meeting is continue in alive status as real persons in the room. Do we need this higher technique to front stand in development for science, may it be necessity at some time as the critical persons cannot meet together to make commander and guidance to medicine events [4].

In summary, E-healthy give us confidence and strength, it has additional supports to our traditional medicine in development, E-Healthy is an assistant branch in medicine, it is useful and valuable to current time.

\section{References}

1. Wang Y (2017) The distance from science to common life. EC Cardiology $3(6): 208$.

2. Hodson R (2018) Digital revolution. Nature 563(7733): S131.

3. Wang Y (1995) Fever and application of antipyretics. The Journal of Clinical Pediatrics 13(1): 59-61.

4. Wang Y (2018) Pediatrics congress in Europe improve development in the world. Archives of Pediatrics and Neonatology 1(2): 12-13.

For possible submissions Click below: 